\title{
Serum Pentraxin-3 Levels Are Associated with the Severity of Metabolic Syndrome
}

\author{
Mehmet Fatih Karakas ${ }^{a}$ Eyup Buyukkaya ${ }^{a}$ Mustafa Kurt ${ }^{a}$ Sedat Motor ${ }^{b}$ \\ Adnan Burak Akcay ${ }^{a}$ Esra Karakas ${ }^{c}$ Şule Buyukkayad Nihat Sen ${ }^{a}$ \\ Departments of a Cardiology, ${ }^{b}$ Clinical Biochemistry, and ${ }^{\mathrm{C} E n d o c r i n o l o g y}$ and Metabolism, Mustafa Kemal \\ University, Tayfur Ata Sokmen Medical School, and d Department of Cardiology, Antakya State Hospital, \\ Antakya, Turkey
}

\author{
Key Words \\ Pentraxin-3 $\cdot$ Metabolic syndrome $\cdot$ High-sensitivity \\ C-reactive protein $\cdot$ Inflammation
}

\begin{abstract}
Objectives: The aim of the present study was to assess the association between the level of pentraxin-3 (PTX-3) and the severity of metabolic syndrome (MS). Subjects and Method: One hundred and two patients with MS and 101 consecutive age- and sex-matched control subjects were included in the study. The MS patients were classified into three groups based on the number of MS criteria, i.e. group 1: patients with 3 MS criteria, group 2: patients with 4 MS criteria, and group 3: patients with 5 MS criteria. Serum PTX-3 and highsensitivity C-reactive protein (hs-CRP) levels were measured. Results: Group 1 had higher PTX-3 levels compared to the control group $(0.58 \pm 0.11 \mathrm{ng} / \mathrm{ml}$ vs. $0.36 \pm 0.15 \mathrm{ng} / \mathrm{ml}, \mathrm{p}<$ 0.001). PTX-3 levels were higher in group 3 than in both group $1(0.90 \pm 0.06 \mathrm{ng} / \mathrm{ml}$ vs. $0.58 \pm 0.11 \mathrm{ng} / \mathrm{ml}, \mathrm{p}<0.001)$ and group $2(0.90 \pm 0.06 \mathrm{ng} / \mathrm{ml}$ vs. $0.63 \pm 0.12 \mathrm{ng} / \mathrm{ml}, \mathrm{p}<$ $0.001)$. Group 3, however, had higher hs-CRP levels than both group 1 (1.89 $\pm 0.45 \mathrm{mg} / \mathrm{dl}$ vs. $1.40 \pm 0.44 \mathrm{mg} / \mathrm{dl}, \mathrm{p}=0.007)$ and group $2(1.89 \pm 0.45 \mathrm{mg} / \mathrm{dl}$ vs. $1.47 \pm 0.58 \mathrm{mg} / \mathrm{dl}, \mathrm{p}=$ 0.01). The control group had lower hs-CRP levels than group
\end{abstract}

\section{KARGER}

E-Mail karger@karger.com www.karger.com/mpp

\section{(c) 2012 S. Karger AG, Basel} 1011-7571/13/0223-0274\$38.00/0

Karger

Open access

This is an Open Access article licensed under the terms of the Creative Commons Attribution-NonCommercial-NoDerivs 3.0 License (www.karger.com/OA-license), applicable to the online version of the article only. Distribution for non-commercial purposes only.
$1(0.81 \pm 0.47 \mathrm{mg} / \mathrm{dl}$ vs. $1.40 \pm 0.44 \mathrm{mg} / \mathrm{dl}, \mathrm{p}<0.001)$ and group $2(0.81 \pm 0.47 \mathrm{mg} / \mathrm{dl}$ vs. $1.47 \pm 0.58 \mathrm{mg} / \mathrm{dl}, \mathrm{p}<0.001)$. Serum PTX-3 levels correlated with serum hs-CRP levels $(r=$ $0.49, p<0.001$ ). Conclusions: PTX-3, a novel inflammatory marker, was found to be associated with the severity of MS.

Copyright $\odot 2012$ S. Karger AG, Basel

\section{Introduction}

Metabolic syndrome (MS) is a cluster of risk factors including glucose intolerance, abnormal lipid profile, hypertension and abdominal obesity, each of which has been shown to be related to atherosclerosis and cardiovascular disease [1-5]. Most of the recent studies showed a correlation between components of MS and inflammatory mediators, namely, interleukin-6, tumor necrosis factor- $\alpha$, and C-reactive protein (CRP) [6, 7]. Moreover, in patients with more risk factors comprising MS, the serum CRP levels were found to be increased and the higher serum CRP levels were associated with a higher prevalence of cardiovascular events which reflects the prognostic significance of the severity of MS [7].

Pentraxin-3 (PTX-3), a newly identified acute-phase reactant which resembles CRP both in structure and 
function [8], has been found to be produced by many kinds of cells such as macrophages, dendritic cells, neutrophils, adipose cells, fibroblasts and vascular endothelial cells $[9,10]$. Plasma PTX-3 levels have recently been found to be elevated in patients with vasculitis [11], acute myocardial infarction $[12,13]$, systemic inflammation or sepsis [14], psoriasis, unstable angina pectoris, and heart failure [15-18]. The association of MS and PTX-3 has not been extensively studied and the published data seem contradictory. Thus, the aim of the present study was to assess the association between the level of PTX-3 and the severity of MS.

\section{Subjects and Methods}

A total of 203 patients were included in this prospective randomized study. One hundred and two patients who were admitted to the outpatient clinic and met the MS criteria were taken as the MS group. One hundred and one age- and sex-matched subjects were the control group. Patients with secondary hypertension, renal failure, hepatic failure and/or manifest heart disease, such as cardiac failure, coronary arterial disease, arrhythmia, and cardiac valve disease, were excluded. Also, patients with infection, acute stress, chronic systemic inflammatory disease, and those receiving medications affecting the number of leukocytes were excluded as well. All participants included in the study were informed about the study, and their oral and written consent was obtained.

MS was diagnosed according to the National Cholesterol Education Program Adult Treatment Panel III criteria 3 (NCEP ATP 3) [3]. Diagnosis was established by the presence of 3 or more of the following criteria: abdominal obesity (waist circumference $>102 \mathrm{~cm}$ in men and $>88 \mathrm{~cm}$ in women); triglyceride level $\geq 150$ $\mathrm{mg} / \mathrm{dl}$ or $\geq 1.7 \mathrm{mmol} / \mathrm{l}$; high-density lipoprotein (HDL) cholesterol level $<40 \mathrm{mg} / \mathrm{dl}$ for men and $<50 \mathrm{mg} / \mathrm{dl}$ for women $(<1.0$ $\mathrm{mmol} / \mathrm{l}$ for men and $<1.3 \mathrm{mmol} / \mathrm{l}$ for women); systolic blood pressure $\geq 130 \mathrm{~mm} \mathrm{Hg}$ and/or diastolic blood pressure $\geq 85 \mathrm{~mm} \mathrm{Hg}$; fasting blood glucose concentration $\geq 110 \mathrm{mg} / \mathrm{dl}$ or $\geq 5.6 \mathrm{mmol} / \mathrm{l}$. Patients were classified into three groups based on the number of MS criteria, i.e. group 1: patients with 3 MS criteria, group 2: patients with $4 \mathrm{MS}$ criteria, and group 3: patients with $5 \mathrm{MS}$ criteria.

Height, weight, and waist circumference were measured while fasting and standing up with standard measuring tools. The narrowest diameter between the costal arch and the anterior superior iliac spine was measured for waist circumference. Body mass index (BMI) and body surface area were calculated using the following formulas: BMI $=$ weight $(\mathrm{kg}) /$ height $(\mathrm{m})^{2}$ and body surface area $\left(\mathrm{m}^{2}\right)=0.007184 \times$ height $(\mathrm{cm})^{0.725} \times$ weight $(\mathrm{kg})^{0.425}$. Blood pressure was measured after at least $10 \mathrm{~min}$ of rest in the sitting position. Blood pressure measurement was repeated two more times at 2-min intervals. The average of the 3 measurements was considered as blood pressure. Venous blood samples obtained in the morning after an 8-hour fast were used to measure serum glucose, urea, creatinine, total cholesterol, triglyceride, HDL, lowdensity lipoprotein, hemoglobin, high-sensitivity CRP (hs-CRP) and PTX-3 levels. Glomerular filtration rate was estimated by the

Pentraxin-3 and Severity of Metabolic Syndrome
Cockcroft-Gault formula. Serum PTX-3 level was measured by enzyme immunoassay using a quantitative kit (Human PTX-3/ TSG-14 Immunoassay, DPTX30; R\&D Systems, Inc., Minn., USA). For PTX-3, intra-assay and interassay coefficients of variation ranged from 3.8 to $4.4 \%$ and from 4.1 to $6.1 \%$, respectively (minimum detectable concentration: $0.025 \mathrm{ng} / \mathrm{ml}$ ). hs-CRP was measured in serum by enzyme immunoassay (Immage hs-CRP EIA kit; Beckman Coulter Inc., USA). Complete blood count was performed in our hematology unit with the Beckman-Coulter Gen-S system device (Beckman-Coulter Inc., USA). Transthoracic echocardiography was performed and ejection fraction was measured by the biplane Simpson method.

\section{Statistical Analyses}

Statistical analyses were conducted with SPSS 17 (SPSS Inc., Chicago, Ill., USA) software package program. Continuous variables were expressed as means \pm standard deviation, whereas categorical variables were presented as percentages. The differences between normally distributed numeric variables were evaluated using the $t$ test or one-way ANOVA, while non-normally distributed variables were analyzed by the Mann-Whitney U test or Kruskal-Wallis variance analysis as appropriate. The $\chi^{2}$ test was employed for the comparison of categorical variables. Univariate correlation and multivariate regression analyses were performed. A p $<0.05$ was considered as statistically significant.

\section{Results}

Baseline clinical and laboratory characteristics of the patients according to groups are shown in table 1. Age, sex, BMI, smoking status and medications were not different amongst all groups. However, BMI and frequencies of hypertension and diabetes mellitus were higher in patients with MS.

Group 1 had higher PTX-3 levels compared to the control group $(0.58 \pm 0.11 \mathrm{ng} / \mathrm{ml}$ vs. $0.36 \pm 0.15 \mathrm{ng} / \mathrm{ml}, \mathrm{p}<$ $0.001)$. The PTX-3 levels were higher in group 3 than both group $1(0.90 \pm 0.06 \mathrm{ng} / \mathrm{ml}$ vs. $0.58 \pm 0.11 \mathrm{ng} / \mathrm{ml}, \mathrm{p}<$ $0.001)$ and group $2(0.90 \pm 0.06 \mathrm{ng} / \mathrm{ml}$ vs. $0.63 \pm 0.12 \mathrm{ng} /$ $\mathrm{ml}, \mathrm{p}<0.001)$. However, group 1 and group 2 had similar PTX-3 levels $(0.58 \pm 0.11 \mathrm{ng} / \mathrm{ml}$ vs. $0.63 \pm 0.12 \mathrm{ng} / \mathrm{ml}$, $\mathrm{p}=0.44)$. On the other hand, there was no difference in levels of hs-CRP between group 1 and group 2 (1.40 \pm $0.44 \mathrm{mg} / \mathrm{dl}$ vs. $1.40 \pm 0.58 \mathrm{mg} / \mathrm{dl}, \mathrm{p}=0.97)$. Group 3 , however, had higher hs-CRP levels than both group 1 (1.89 \pm $0.45 \mathrm{mg} / \mathrm{dl}$ vs. $1.40 \pm 0.44 \mathrm{mg} / \mathrm{dl}, \mathrm{p}=0.007$ ) and group 2 $(1.89 \pm 0.45 \mathrm{mg} / \mathrm{dl}$ vs. $1.47 \pm 0.58 \mathrm{mg} / \mathrm{dl}, \mathrm{p}=0.01)$. The control group had lower hs-CRP levels than group 1 ( 0.81 $\pm 0.47 \mathrm{mg} / \mathrm{dl} \mathrm{vs} .1 .40 \pm 0.44 \mathrm{mg} / \mathrm{dl}, \mathrm{p}<0.001$ ) and group $2(0.81 \pm 0.47 \mathrm{mg} / \mathrm{dl}$ vs. $1.47 \pm 0.58 \mathrm{mg} / \mathrm{dl}, \mathrm{p}<0.001)$ (fig. 1). Univariate correlation analysis revealed a positive correlation between serum PTX-3 levels and hs-CRP levels $(r=0.49, p<0.001)$ (fig. 2). In the multivariate linear 
Table 1. Baseline clinical and laboratory characteristics of patient groups

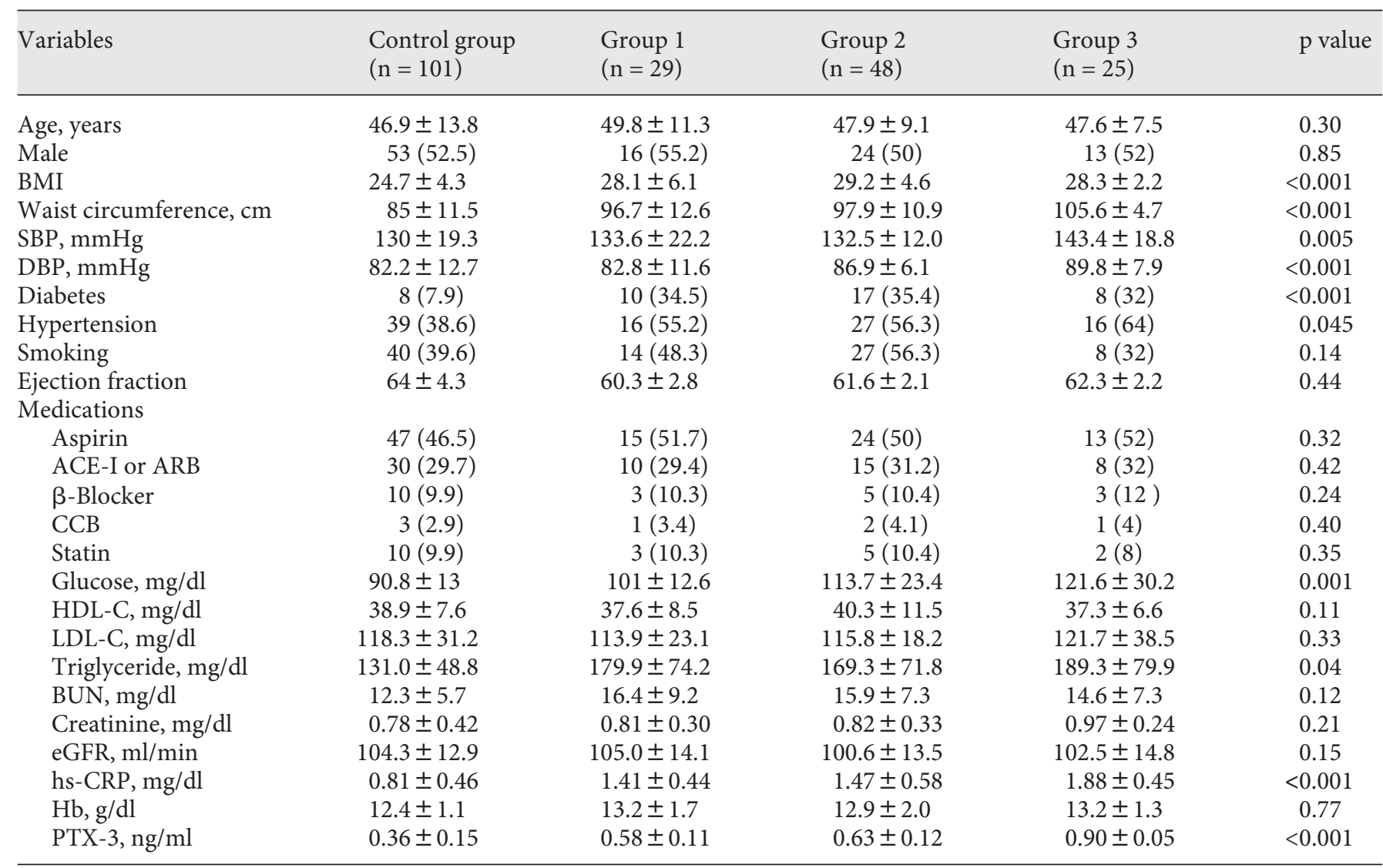

$\mathrm{SBP}=$ Systolic blood pressure; DBP = diastolic blood pressure; $\mathrm{ACE}-\mathrm{I}=$ angiotensin-converting enzyme inhibitor; $\mathrm{ARB}=$ angiotensin receptor blocker; $\mathrm{BUN}=$ blood urea nitrogen; $\mathrm{CCB}=$ calcium channel blocker; eGFR = estimated glomerular filtration rate; HDL-C = high-density lipoprotein cholesterol; LDL-C = low-density lipoprotein cholesterol. Categorical variables were expressed as numbers with percentages in parentheses whereas numerical variables were expressed as means \pm standard deviation. The comparisons between groups were done by the $\chi^{2}$ or
Kruskal Wallis test where appropriate. $\mathrm{p}$ values are overall trend values between groups and $\mathrm{p}<0.05$ was considered as significant. The comparison between the control group and group 1 was done by the Mann-Whitney $U$ test and $\chi^{2}$ test. The significant $p$ values for these two groups were as follows: BMI, $p=0.005$; waist circumference, $\mathrm{p}<0.001$; diabetes mellitus, $\mathrm{p}=0.001$; glucose, $\mathrm{p}<0.001$; triglyceride, $\mathrm{p}<0.001$; BUN, $\mathrm{p}=0.045$; hs-CRP, $\mathrm{p}=0.001$; PTX-3, $\mathrm{p}<0.001$. regression analysis, serum PTX-3 was found to be independently correlated with age $(\beta=-0.11, p=0.044)$, glucose level $(\beta=0.23, p<0.001)$, waist circumference $(\beta=$ $0.37, \mathrm{p}<0.001)$ and HDL cholesterol $(\beta=-0.31, \mathrm{p}<001)$.

\section{Discussion}

PTX-3, a novel inflammatory marker, was significantly higher in MS groups than the control group, and serum PTX-3 levels increased as the severity of MS increased. Many recent studies have shown that there is a correlation between components of MS and inflammatory mediators, namely, interleukin-6, tumor necrosis factor- $\alpha$, and CRP [6]. Among these inflammatory biomarkers, the best characterized and standardized is the hs-CRP [19]. hs-CRP has been shown to be associated with insulin resistance [20], endothelial dysfunction $[2,21]$ and adverse cardiovascular events [7,22].

PTX-3 is produced by different kinds of cells such as adipocytes, macrophages, dendritic cells, neutrophils, fibroblasts, vascular endothelial cells $[9,10]$ and released by inflammatory stimuli and known cardiovascular risk factors, including oxidized low-density lipoprotein [23, 
Fig. 1. The mean PTX-3 and hs-CRP levels according to groups.

Fig. 2. Correlation plots for PTX-3 and hsCRP.
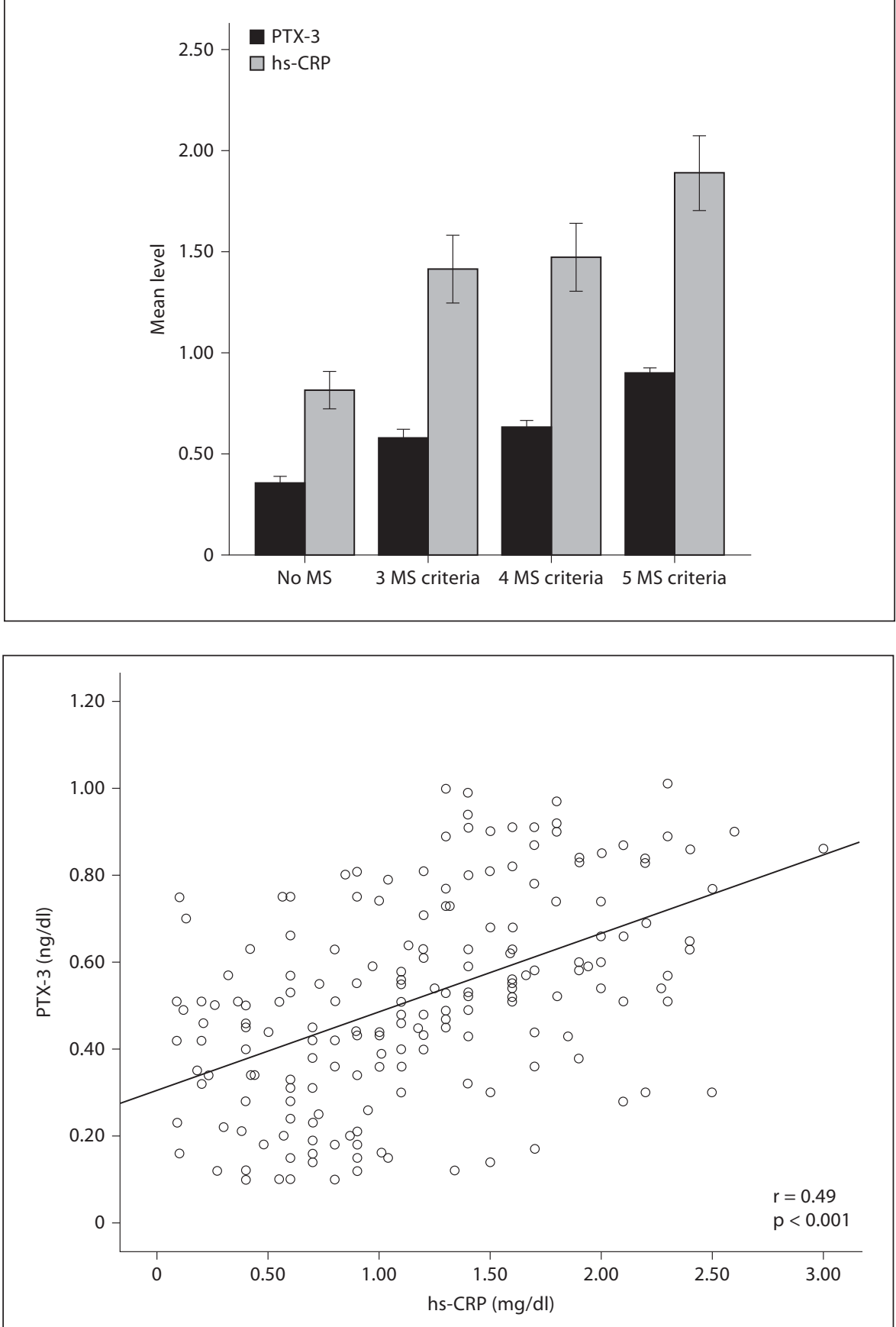

24]; therefore, it may reflect the local inflammatory status in tissues [16]. Zanetti et al. [20] reported that the hs-CRP and the PTX-3 levels were higher in MS patients and they postulated that this elevation was related to inflammation and subclinical atherosclerosis. Another study reported that plasma PTX-3 levels were lower in individuals who had more than one MS component compared to

Pentraxin-3 and Severity of Metabolic Syndrome healthy individuals. In the same study, however, hs-CRP levels were higher in individuals who had more than one MS component. They postulated that PTX-3 and CRP antagonistically participate in the development of MS. In the present study, we found that PTX-3 levels were higher in MS patients and as the number of MS components increased, the PTX-3 and the hs-CRP levels also increased. 
This result seems to conflict with the aforementioned study. In their paper, they postulated that lower PTX-3 levels might be associated with the HDL cholesterol-induced PTX-3 inhibition. In fact, in our study, the included patients were different from those of the aforementioned study, which included only healthy males without any disease or medication. Firstly, most of our patients had risk factors such as hypertension, diabetes mellitus and therefore had an inflammatory background. In addition, the patients in our study had relatively lower HDL cholesterol levels. This may be the reason why PTX-3 levels were higher as the number of MS components increased. PTX-3 was well correlated with hs-CRP levels, which supports the baseline inflammatory background. The reason why the patients with $5 \mathrm{MS}$ components had higher PTX-3 and hs-CRP levels compared to patients with 3 or 4 components may be explained by the synergistic interactions of the 5 components resulting in an increased inflammatory status. Although elevated PTX-3 levels were found to be associated with adverse cardiovas- cular events in stable coronary artery disease [25] and acute coronary syndromes $[13,26]$, there is a lack of data about the prognostic significance of elevated PTX-3 in MS. Seemingly, for a more thorough understanding of the role of PTX-3 in MS, further studies are needed.

The major limitation of this study was the number $(n=203)$ of patients included. Another limitation was the lack of long-term follow-up of the patients, which could have provided prognostic information about the levels of PTX-3. Inflammatory markers other than hs-CRP such as interleukin- 6 and tumor necrosis factor- $\alpha$ would support collecting more data about the inflammatory status.

\section{Conclusion}

PTX-3, a novel inflammatory marker, was associated with the severity of MS, which may reflect a higher inflammatory status associated with the increased number of components comprising MS.

\section{References}

1 Grundy SM, Brewer HB Jr, Cleeman JI, Smith SC Jr, Lenfant C: Definition of metabolic syndrome: report of the National Heart, Lung, and Blood Institute/American Heart Association conference on scientific issues related to definition. Circulation 2004;109:433-438.

-2 Venugopal SK, Devaraj S, Yuhanna I, Shaul P, Jialal I: Demonstration that C-reactive protein decreases eNOS expression and bioactivity in human aortic endothelial cells. Circulation 2002;106:1439-1441.

-3 Executive Summary of the Third Report of the National Cholesterol Education Program (NCEP) Expert Panel on Detection, Evaluation, and Treatment of High Blood Cholesterol in Adults (Adult Treatment Panel III). JAMA 2001;285:2486-2497.

4 Williams S, Cunningham E, Pories WJ: Surgical treatment of metabolic syndrome. Med Princ Pract 2012;21:301-309.

-5 Sorkhou EI, Al-Qallaf B, Al-Namash HA, Ben-Nakhi A, Al-Batish MM, Habiba SA: Prevalence of metabolic syndrome among hypertensive patients attending a primary care clinic in Kuwait. Med Princ Pract 2004; 13:39-42.

6 Yudkin JS, Stehouwer CD, Emeis JJ, Coppack SW: C-reactive protein in healthy subjects: associations with obesity, insulin resistance, and endothelial dysfunction: a potential role for cytokines originating from adipose tissue? Arterioscler Thromb Vasc Biol 1999;19: 972-978.
7 Ridker PM, Buring JE, Cook NR, Rifai N: Creactive protein, the metabolic syndrome, and risk of incident cardiovascular events: an 8-year follow-up of 14,719 initially healthy American women. Circulation 2003;107: 391-397.

-8 Hansson GK: Inflammation, atherosclerosis, and coronary artery disease. $\mathrm{N}$ Engl J Med 2005;352:1685-1695.

-9 Brown DW, Giles WH, Croft JB: White blood cell count: an independent predictor of coronary heart disease mortality among a national cohort. J Clin Epidemiol 2001;54:316322.

$\checkmark 10$ Abderrahim-Ferkoune A, Bezy O, Chiellini C, Maffei M, Grimaldi P, Bonino F, MoustaidMoussa N, Pasqualini F, Mantovani A, Ailhaud $\mathrm{G}$, et al: Characterization of the long pentraxin PTX3 as a TNFalpha-induced secreted protein of adipose cells. J Lipid Res 2003;44:994-1000.

11 Fazzini F, Peri G, Doni A, Dell'Antonio G, Dal Cin E, Bozzolo E, D’Auria F, Praderio L, Ciboddo G, Sabbadini MG et al: PTX3 in small-vessel vasculitides: an independent indicator of disease activity produced at sites of inflammation. Arthritis Rheum 2001;44: 2841-2850.
12 Amit M, Carpenter MK, Inokuma MS, Chiu CP, Harris CP, Waknitz MA, Itskovitz-Eldor J, Thomson JA: Clonally derived human embryonic stem cell lines maintain pluripotency and proliferative potential for prolonged periods of culture. Dev Biol 2000;227:271278 .

13 Latini R, Maggioni AP, Peri G, Gonzini L, Lucci D, Mocarelli P, Vago L, Pasqualini F, Signorini S, Soldateschi D, et al: Prognostic significance of the long pentraxin PTX3 in acute myocardial infarction. Circulation 2004;110:2349-2354.

14 Muller B, Peri G, Doni A, Torri V, Landmann R, Bottazzi B, Mantovani A: Circulating levels of the long pentraxin PTX3 correlate with severity of infection in critically ill patients. Crit Care Med 2001;29:1404-1407.

-15 Bevelacqua V, Libra M, Mazzarino MC, Gangemi P, Nicotra G, Curatolo S, Massimino D, Plumari A, Merito P, Valente G, et al: Long pentraxin 3: a marker of inflammation in untreated psoriatic patients. Int J Mol Med 2006;18:415-423.

16 Inoue K, Sugiyama A, Reid PC, Ito Y, Miyauchi K, Mukai S, Sagara M, Miyamoto K, Satoh H, Kohno I, et al: Establishment of a high sensitivity plasma assay for human pentraxin 3 as a marker for unstable angina pectoris. Arterioscler Thromb Vasc Biol 2007;27:161167. 
17 Suzuki S, Takeishi Y, Niizeki T, Koyama Y, Kitahara T, Sasaki T, Sagara M, Kubota I: Pentraxin 3, a new marker for vascular inflammation, predicts adverse clinical outcomes in patients with heart failure. Am Heart J 2008;155:75-81.

18 Matsubara J, Sugiyama S, Nozaki T, Sugamura K, Konishi M, Ohba K, Matsuzawa Y, Akiyama E, Yamamoto E, Sakamoto K, et al: Pentraxin 3 is a new inflammatory marker correlated with left ventricular diastolic dysfunction and heart failure with normal ejection fraction. J Am Coll Cardiol 2011;57: 861-869.

19 Frayn KN: Insulin resistance, impaired postprandial lipid metabolism and abdominal obesity. A deadly triad. Med Princ Pract 2002;11(suppl 2):31-40.
20 Zanetti M, Bosutti A, Ferreira C, Vinci P, Biolo G, Fonda M, Valente M, Cattin L, Guarnieri G, Barazzoni R: Circulating pentraxin 3 levels are higher in metabolic syndrome with subclinical atherosclerosis: evidence for association with atherogenic lipid profile. Clin Exp Med 2009;9:243-248.

21 Verma S, Wang CH, Li SH, Dumont AS, Fedak PW, Badiwala MV, Dhillon B, Weisel RD, Li RK, Mickle DA et al: A self-fulfilling prophecy: C-reactive protein attenuates nitric oxide production and inhibits angiogenesis. Circulation 2002;106:913-919.

-22 Ridker PM, Pare G, Parker A, Zee RY, Danik JS, Buring JE, Kwiatkowski D, Cook NR, Miletich JP, Chasman DI: Loci related to metabolic-syndrome pathways including LEPR, HNF1A, IL6R, and GCKR associate with plasma C-reactive protein: the Women's Genome Health Study. Am J Hum Genet 2008; 82:1185-1192.

23 Klouche M, Peri G, Knabbe C, Eckstein HH, Schmid FX, Schmitz G, Mantovani A: Modified atherogenic lipoproteins induce expression of pentraxin-3 by human vascular smooth muscle cells. Atherosclerosis 2004; 175:221-228.
24 Breviario F, d'Aniello EM, Golay J, Peri G, Bottazzi B, Bairoch A, Saccone S, Marzella R, Predazzi V, Rocchi M et al: Interleukin-1-inducible genes in endothelial cells. Cloning of a new gene related to $\mathrm{C}$-reactive protein and serum amyloid $\mathrm{P}$ component. J Biol Chem 1992;267:22190-22197.

25 Jenny NS, Arnold AM, Kuller LH, Tracy RP, Psaty BM: Associations of pentraxin 3 with cardiovascular disease and all-cause death: the Cardiovascular Health Study. Arterioscler Thromb Vasc Biol 2009;29:594-599.

26 Matsui S, Ishii J, Kitagawa F, Kuno A, Hattori K, Ishikawa M, Okumura M, Kan S, Nakano T, Naruse H, et al: Pentraxin 3 in unstable angina and non-ST-segment elevation myocardial infarction. Atherosclerosis 2010; 210:220-225. 